\title{
Micropropagation of Dalbergia nigra, an endangered Brazilian forest tree
}

Rodrigo Oliveira Almeida ${ }^{1}$

Sarah Santos da Silva ${ }^{2}$

Ana Catarina Monteiro Carvalho Mori da Cunha ${ }^{3}$

\section{Abstract}

We report in this work an in vitro propagation method for Dalbergia nigra using nodal segments from germinated seeds in vitro. Plant material was cultivated on MS medium supplemented with 6-benzyladeninepurine (BAP: $0 \mu \mathrm{M}, 1.11 \mu \mathrm{M}$ and $2.22 \mu \mathrm{M}$ ) and Naphthaleneacetic acid (NAA: $0.27 \mu \mathrm{M}$ ), combined with different amounts of subcultures for induction of shoot multiplication. Multiplied shoots were inoculated in MS and $1 / 2$ MS medium (half strength of MS salts) to root, supplemented with NAA $(0 \mu \mathrm{M}$ and $4 \mu \mathrm{M})$. Data were analyzed by non-parametric statistical Kruskal-Wallis test. Best results to shoot multiplication were obtained using $1.11 \mu \mathrm{M}$ or $2.22 \mu \mathrm{M}$ of BAP combined $0.27 \mu \mathrm{M}$ of NAA in multiplication medium and performing three subcultures, providing higher rates of shoots production per explant (average of 2.24) and high survival rate. Best results for rooting of shoots generated were obtained using a rooting medium containing $1 / 2 \mathrm{MS}$ supplemented with $4 \mu \mathrm{M}$ of NAA, providing a higher percentage of shoot rooting (average of $68 \%$ ).

Keywords: Jacarandá-da-Bahia. In vitro propagation. Organogenesis.

\section{Introduction}

Dalbergia nigra, also known as jacarandá-da-bahia, has originated in the Brazilian Atlantic Forest biome. This biome has already undergone several phases of exploration, with logging being one of the main responsible causes of severe damage, destroying large areas of forest (FEARNSIDE, 2006; GONZAGA, 2006). Due to the exploitation and the great difficulty of natural regeneration, the species $D$. nigra was classified as vulnerable, being present in official documents of the Brazilian government (MMA, 2014). Although forest reminders continue to suffer devastation, the Brazilian government has required from the logging companies more dedication to recover these degraded areas. Considering the reforestation need, some Brazilian native species have shown great potential in projects with an environmental focus, as forest restoration in degraded areas and landscape recomposition, being better adapted to the edaphoclimatic conditions and acting on the soil recovery (NIETSCHE et al., 2004). In this context, D. nigra presents great potential to be used in this process previously cited (GONÇALVES et al., 2014). Seedlings of native woody species to be used in reforestation projects must have characteristics of resistance, vigor, and phytosanitary quality (MARTINS, 2010). Nevertheless, the amount of $D$. nigra seedling produced in many plant nursery is insufficient to perform a degraded area recovery project, due to the few amount of seed collected. To overcome this bottleneck, biotechnological tools such as

1 Instituto Federal de Educação, Ciência e Tecnologia do Sudeste de Minas Gerais (IF SUDESTE MG) - Campus Muriaé. Doutor em Biotecnologia. rodrigo.almeida@ifsudestemg.edu.br. Muriaé, Minas Gerais, Brasil, CEP 36884-036

2 IF SUDESTE MG - Campus Rio Pomba. Bacharela em Agroecologia. sarahs2209@hotmail.com.

3 Instituto Federal de Educação, Ciência e Tecnologia do Alagoas. Doutora em Ciência Florestal. catarina_mori@yahoo.com.br. 
plant micropropagation have shown great utility in the production of seedlings of several economically important or endangered forest species (MARTIN et al., 2006, SANJAYA; RATHORE; RAI, 2006, TRIPATHI; KUMARI, 2010), where in vitro periodic subcultures of a single explant can generate numerous forest seedlings (BONGA; VON ADERKAS, 1992). Nevertheless, a well-formed micropropagation protocol to $D$. nigra is absent. In vitro propagation of Brazilian native forest species is still very early, with some works using species such as Amburana acreana (Ducke) A.C. Smith (FERMINO JUNIOR; SCHERWINSKI-PEREIRA, 2012), Aspidosperma ramiflorum Muell. Arg. (HUBNER et al., 2007), Aspidosperma polyneuron (RIBAS et al., 2005) and Albizia niopoides (ROSSI; SARTORETTO, 2013).

Therefore, the present work aimed to define a rapid and reproducible method for the in vitro propagation and multiplication of Dalbergia nigra for seedling production.

\section{Materials and methods}

The present research was conducted in the plant tissue culture laboratory at Instituto Federal de Educação, Ciência e Tecnologia do Sudeste de Minas Gerais. The D. nigra seeds were collected in

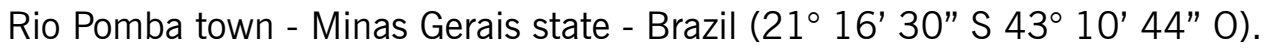

\section{Plant material and surface sterilization}

The seeds were disinfected with $70 \%$ ethanol (1 min), sodium hypochlorite $(\mathrm{NaOCl}) 2 \%$ (15 min), washed 3 times with autoclaved distilled water in a laminar air flow cabinet, and then inoculated in $250 \mathrm{ml}$ vials (with polypropylene cap) containing autoclaved sand and maintained at $25 \pm 2{ }^{\circ} \mathrm{C}, 16$ hours of photoperiod and light intensity of $50 \mu$ moles $\mathrm{m}^{-2} \mathrm{~s}^{-1}$.

\section{Establishment of nodal segments}

Nodal segments collected from seedlings previously germinated in autoclaved sand were disinfested (same process described above for seeds). Then, the plant material was inoculated into test tubes (20 mm x $150 \mathrm{~mm}$ ) containing $10 \mathrm{~mL}$ of semi-solid MS medium (MURASHIGE; SKOOG, 1962), supplemented with $30 \mathrm{~g} \mathrm{~L}$ of sucrose, $7 \mathrm{~g} \mathrm{~L}$ of agar, and $1.5 \mathrm{~g} \mathrm{~L}$ of PVP (polyvinylpyrrolidone), with $\mathrm{pH}$ adjusted to 5.8 before autoclaving ( $120^{\circ} \mathrm{C}$ for 15 minutes) and maintained under the same conditions described above for the seeds.

\section{Multiplication of shoots}

Previously established nodal segments were inoculated into test tubes (20 mm x $150 \mathrm{~mm}$ ) containing $10 \mathrm{~mL}$ of semi-solid MS medium supplemented with $0.27 \mu \mathrm{M}$ of NAA (naphthaleneacetic acid) and BAP (6-benzylaminopurine) at concentrations $0 \mu \mathrm{M}, 1.11 \mu \mathrm{M}$, and 2.22 $\mu \mathrm{M}$ (Treatment 1, 2 and 3 ) and maintained at $25 \pm 2{ }^{\circ} \mathrm{C}, 16$ hours of photoperiod and light intensity of $50 \mu \mathrm{moles} \mathrm{m}^{-2} \mathrm{~s}^{-1}$. Every 30 days, the explants were evaluated and subcultured (Subculture 1, 2, and 3) in a fresh multiplication medium. The experimental design was completely randomized in a factorial scheme, with 10 replicates per treatment and five explants per replicate. The survival rate (shoots with healthy tissue), the number of buds formed, and the number of leaves formed were evaluated at each subculture time.

\section{Rooting of shoots multiplied}

Shoots from the multiplication process were inoculated in test tubes (20 mm x $150 \mathrm{~mm}$ ) containing $10 \mathrm{~mL}$ of semi-solid complete MS medium and $1 / 2 \mathrm{MS}$ (half strength of MS salts), with and without supplementation of NAA (MS + $0 \mu \mathrm{M}$ NAA; MS $+4 \mu \mathrm{M} N A$; $1 / 2 \mathrm{MS}+0 \mu \mathrm{M}$ NAA and 
$1 / 2 \mathrm{MS}+4 \mu \mathrm{M} \mathrm{NAA}$ ), all containing $30 \mathrm{~g} \mathrm{~L}$ of sucrose, $7 \mathrm{~g} \mathrm{~L}$ of agar, $1.5 \mathrm{~g} \mathrm{~L}$ of PVP (polyvinylpyrrolidone). All material was maintained at $25 \pm 2{ }^{\circ} \mathrm{C}$, in the absence of light. After 5 days, the explants were subcultured in test tubes $\left(20 \mathrm{~mm} \times 150 \mathrm{~mm}\right.$ ) containing $10 \mathrm{~mL}$ of semi-solid MS medium, at $25 \pm 2{ }^{\circ} \mathrm{C}$, 16 hours of photoperiod and light intensity of $50 \mu$ moles $\mathrm{m}^{-2} \mathrm{~s}^{-1}$. The experimental design was completely randomized with five replicates ( 5 explants per replicate) per treatment. The number of rooted multiplied shoots was evaluated after 45 days.

\section{Statistical analysis}

The data were analyzed using $R$ language ( $R$ Core Team, 2018) version 3.4.1 alongside the package agricolae (DE MENDIBURU, 2014) to perform the statistical tests (ANOVA or Kruskal-Wallis).

\section{Results and discussion}

Normality and homogeneity of variances tests were performed using Shapiro-Wilk (SHAPIRO; WILK, 1965) and Bartlett (BARTLETT, 1937) tests, respectively (data not shown). Since the data did not meet the statistical assumptions of an ANOVA, the non-parametric Kruskal-Wallis test was performed. Shoots multiplication data were analyzed in relation to subcultures independent of the treatments (FIGURE 1A), treatments independent of the number of subcultures (FIGURE 1B), treatments within each subculture (FIGURE 1C), and subcultures within each treatment (FIGURE 1D).

Figure 1 - Explants of $D$. nigra under action of different treatments and amount of subculture to shoot multiplication.
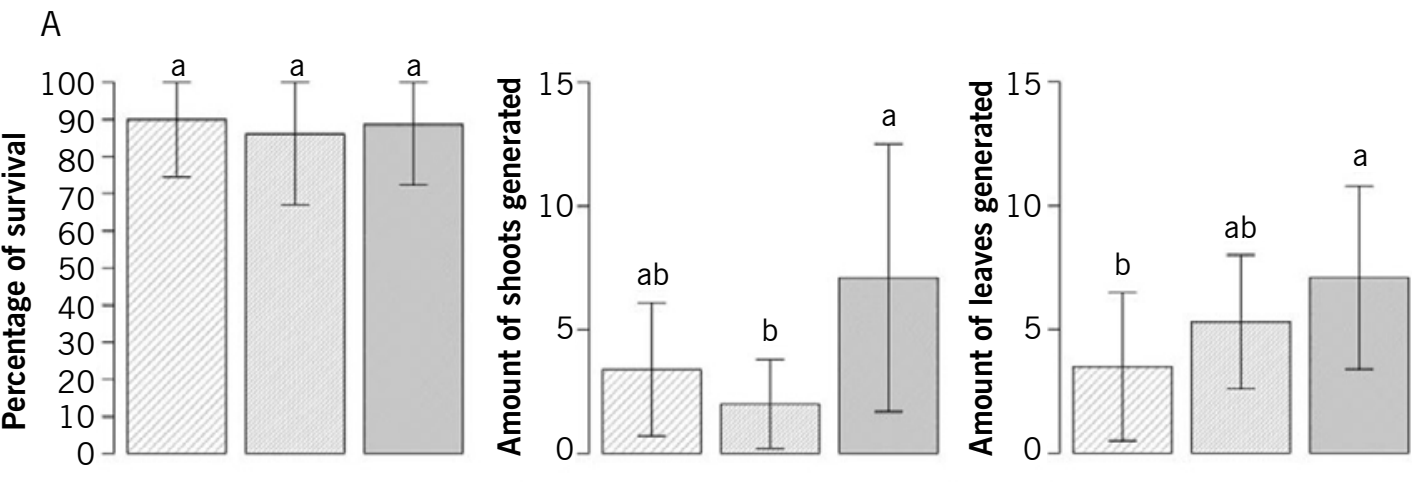

口Subculture 1 aSubculture 2 aSubculture 3
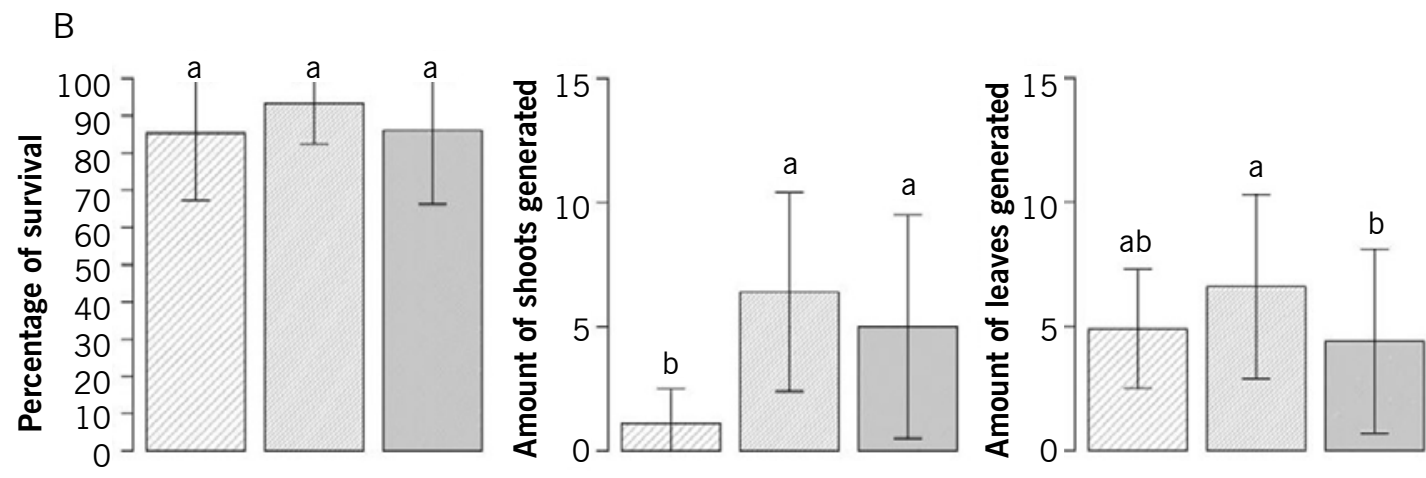

- Treatment 1 aTreatment 2 - Treatment 3

(continue...) 
Figure 1 - Continuation

C

Subculture 1

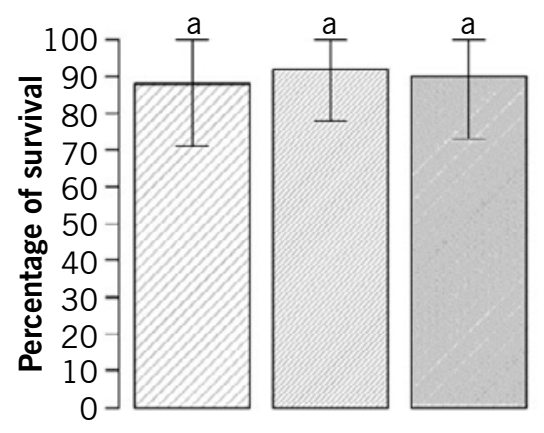

Subculture 2
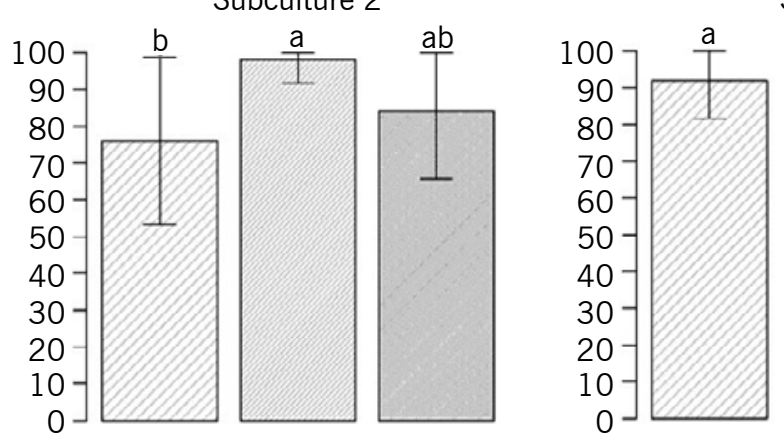

Subculture 3
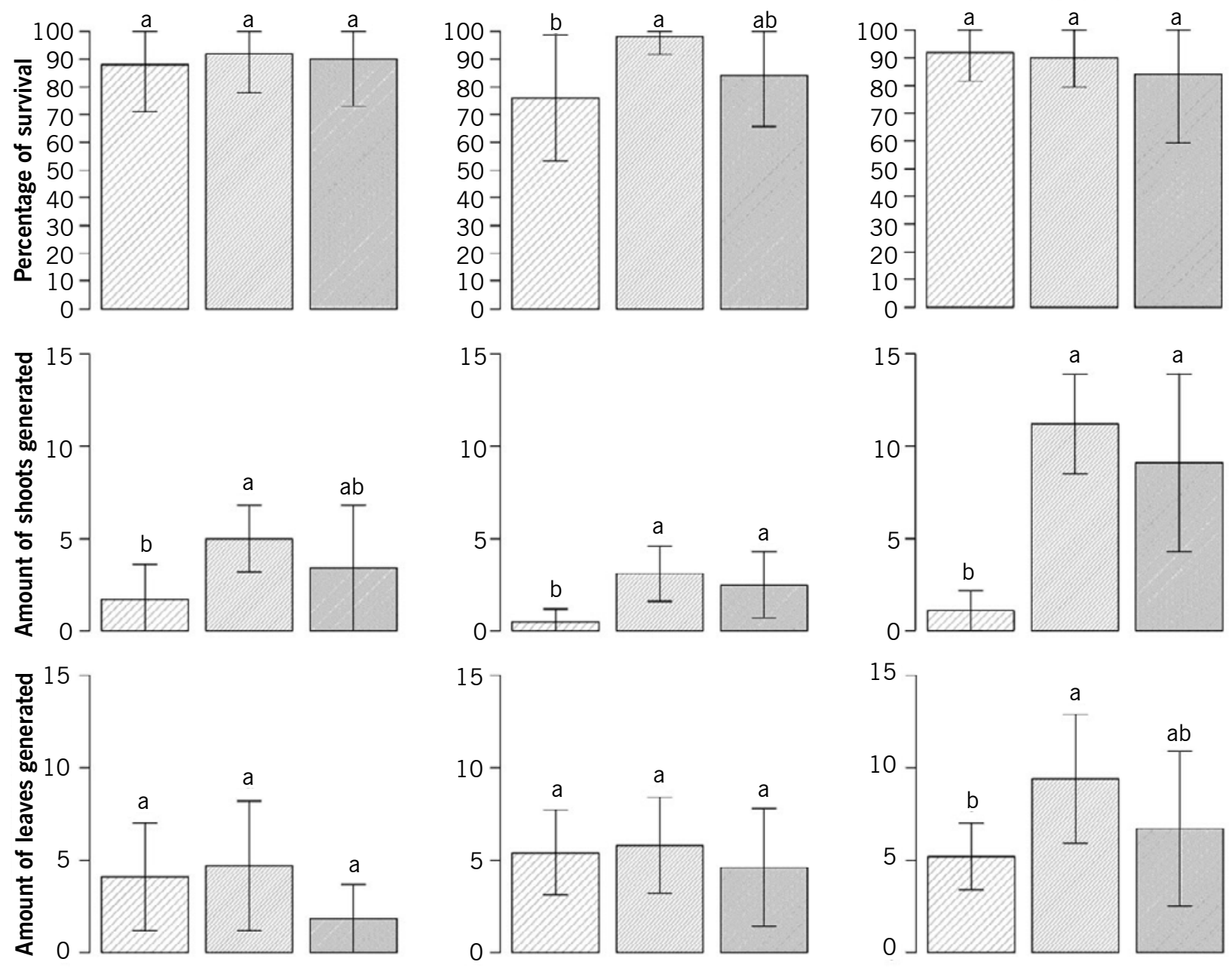

$\square$ Treatment $1 \square$ Treatment $2 \square$ Treatment 3

(continue...) 
Figure 1 - Continuation

$\mathrm{D}$

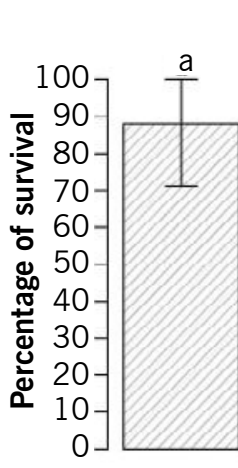

Treatment 1
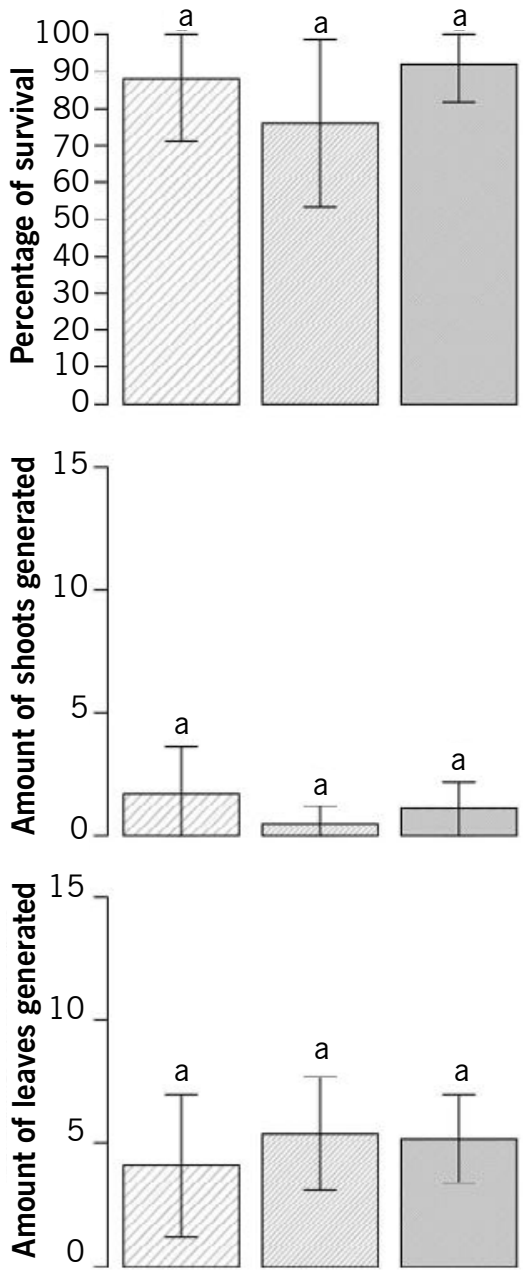

Treatment 2
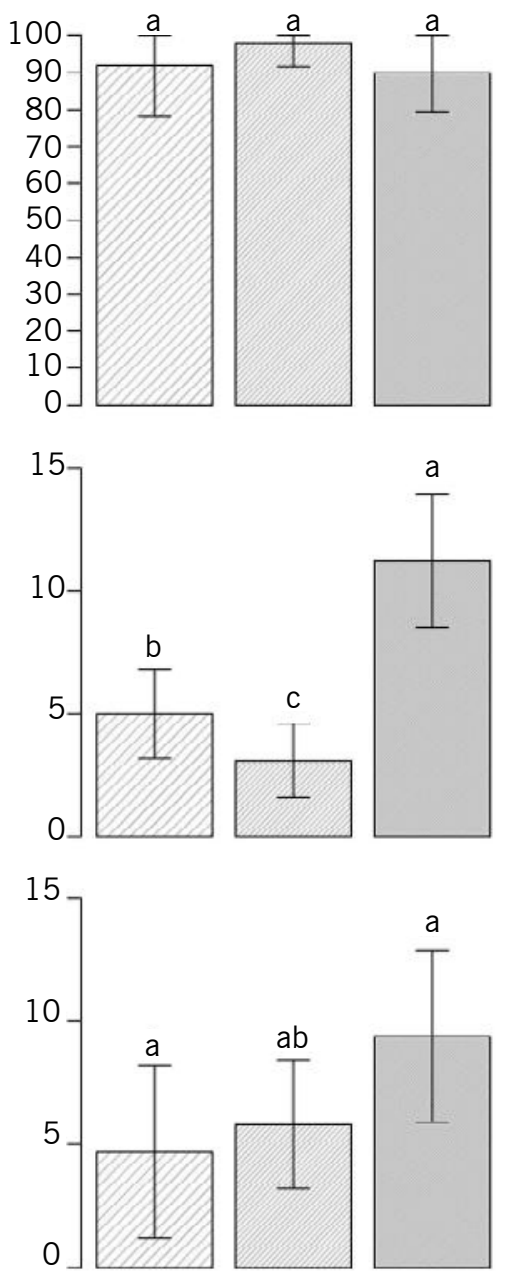

Treatment 3
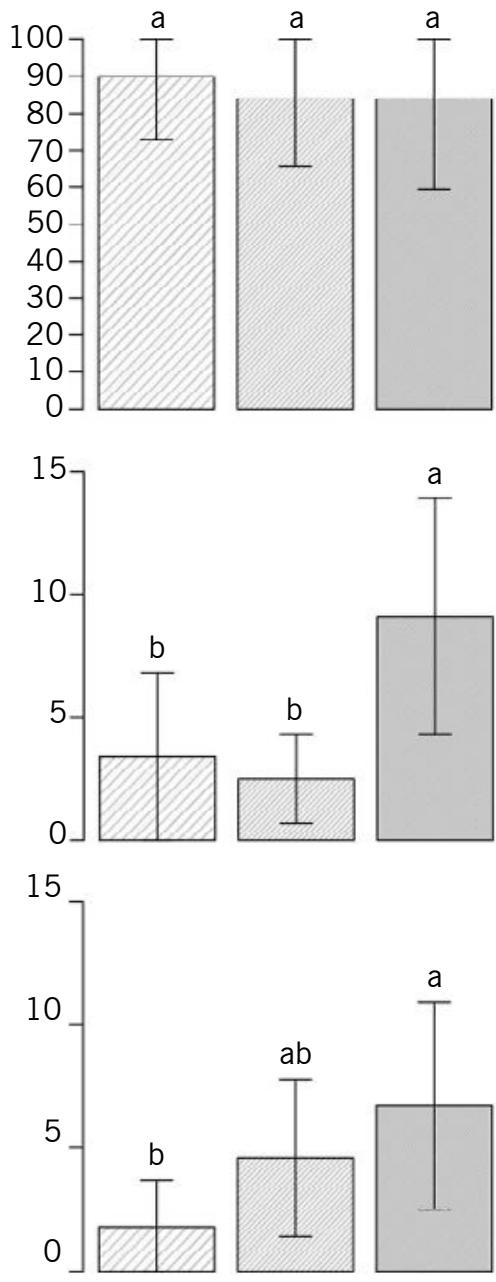

\section{$\square$ Subculture $1 \square$ Subculture $2 \square$ Subculture 3}

A. Subculture effect independent of the treatments; B. Treatments effect independent of the amount of subculture; C. Treatments within each subculture; D. Subculture effect within each multiplication treatments. Subculture 1: after 30 days of inoculation; Subculture 2: after 60 days of inoculation; Subculture 3: after 90 days of inoculation. Treatment 1: MS medium without supplementation of BAP; Treatment 2: MS medium supplemented with $1.11 \mu \mathrm{M}$ of BAP; Treatment 3: MS medium supplemented with $2.22 \mu \mathrm{M}$ of BAP.

Averages followed by the same letter do not differ by the Kruskal-Wallis test followed by the post hoc test Fisher's Least Significant Difference ( $p \leq 0.05)$.

Source: Elaborated by the authors (2019).

Best results are observed using $1.11 \mu \mathrm{M}$ and $2.22 \mu \mathrm{M}$ of BAP (treatment 2 and 3 , respectively) and performing three subcultures, obtaining an average of 11.2 shoots and 9.4 leaves (using $1.11 \mu \mathrm{M}$ of BAP) and an average of 9.1 shoots and 6.7 leaves (using $2.22 \mu \mathrm{M}$ of BAP). However, the survival rate of the explants does not show a significant difference, being an exception only when the data are compared between treatments and performing two subcultures. Data of rooting rate of the multiplied shoots show best results using treatment $1 / 2 \mathrm{MS}+4 \mu \mathrm{M}$ of NAA (Treatment 4) (FIGURE 2). 
Figure 2 - Shoots of $D$. nigra from multiplication medium under the action of the rooting medium after 45 days.

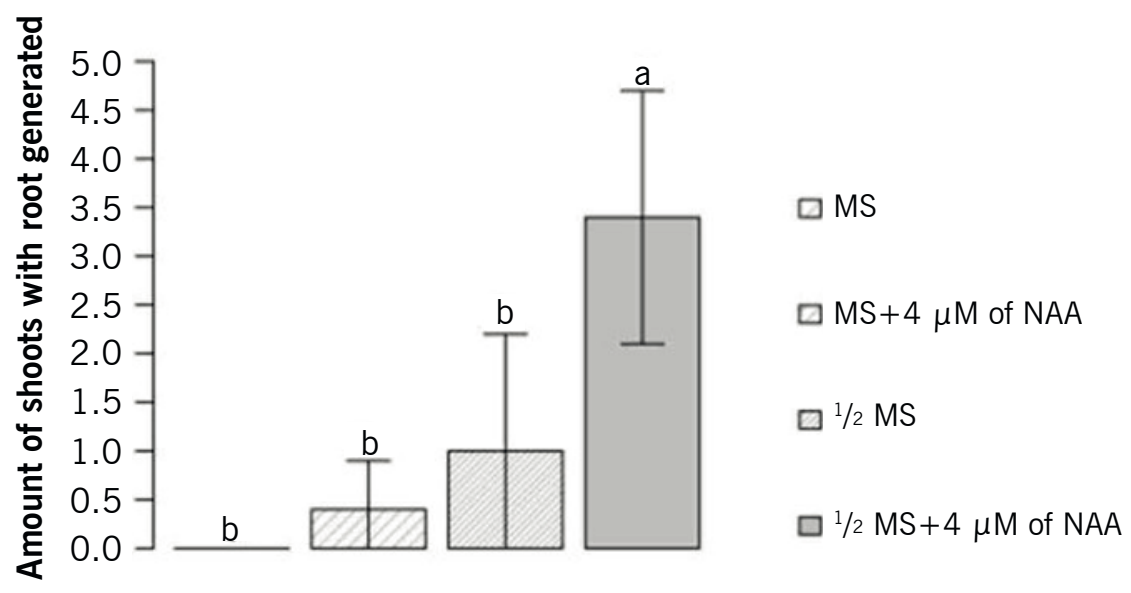

Treatments

Averages followed by the same letter do not differ by the Kruskal-Wallis test followed by the post hoc test Fisher's Least Significant Difference ( $p \leq 0.05)$.

Source: Elaborated by the authors (2019).

High survival rates of nodal segments in the Dalbergia nigra multiplication phase shows high vigor of the selected tissues after the establishment phase. However, the manipulation of explants at each cultivation may influence the survival rate, and may decrease the number of surviving explants, since the excision of new shoots to posterior subculture leaves explants subject to stress, generating phenolic compounds and thus increasing the explant oxidation (PHULWARIA et al., 2011). Another factor of important contribution to greater vigor of the explants and consequently reaching a higher rate of survival is the maintenance of the nutritional balance offered. Once the culture medium was renewed at each subculture, the explants vigor was maintained, and shoot multiplication increase (PHULWARIA et al., 2011). Even without having BAP growth regulator in the culture medium, small amounts of shoots were produced by treatment without BAP (treatment 1), probably due to the endogenous concentrations of growth regulators in the explants. The same was reported in explants of Amburana acreana (FERMINO JÚNIOR; SCHERWINSKI-PEREIRA, 2012) and Aspidosperma polyneuron (RIBAS et al., 2005). In our present study, the multiplication rate of the plant material reached a maximum value of 2.4 shoots (average of treatment) per explant (Supplemented material T1). Fermino Júnior, Nagao and Scherwinski-Pereira (2009) were able to obtain 1.75 shoots per explant, working with Tectona grandis, while Hubner et al. (2007) reached from 1.8 to 3.0 shoots per explant, working with Aspidosperma ramiflorum.

The rooting rate reached a maximum value of 3.4 roots (average of treatment) per replicate (Supplemented material - Table 2). The high concentration of salts that make up the MS basic medium, even in presence of auxins, may inhibit in vitro rooting (LLOYD; McCOWN, 1981). The responses of $D$. nigra explant were high using MS semi-solid medium supplemented with $1.11 \mu \mathrm{M}$ and $2.22 \mu \mathrm{M}$ of BAP (multiplication medium) and $1 / 2 \mathrm{MS}$ semi-solid medium supplemented with $4 \mu \mathrm{M}$ of NAA (rooting medium) ( FIGURE 3).

Kruskal-Wallis test results show no significant difference only to survival rate data. It is usual for researches to use the ANOVA statistic test (sometimes, without performing a test of normality and homogeneity of variances) to analyse the plant tissue culture data, followed by post hoc test of 
Duncan (PHULWARIA et al., 2012), SNK (FERMINO JUNIOR; SCHERWINSKI-PEREIRA, 2012), Tukey (ROSSI, SARTORETTO, 2013) or t-test and deviance analysis (generalized linear model - GLM) followed by the post hoc test of Tukey (ZANELLA et al., 2018). Nevertheless, this kind of data generally does not belong to a Gaussian distribution, but to Poison distribution. Thus, Kruskal-Wallis test can be applied in plant tissue culture data.

Figure 3 - Explants of $D$. nigra under action of multiplication and rooting medium.
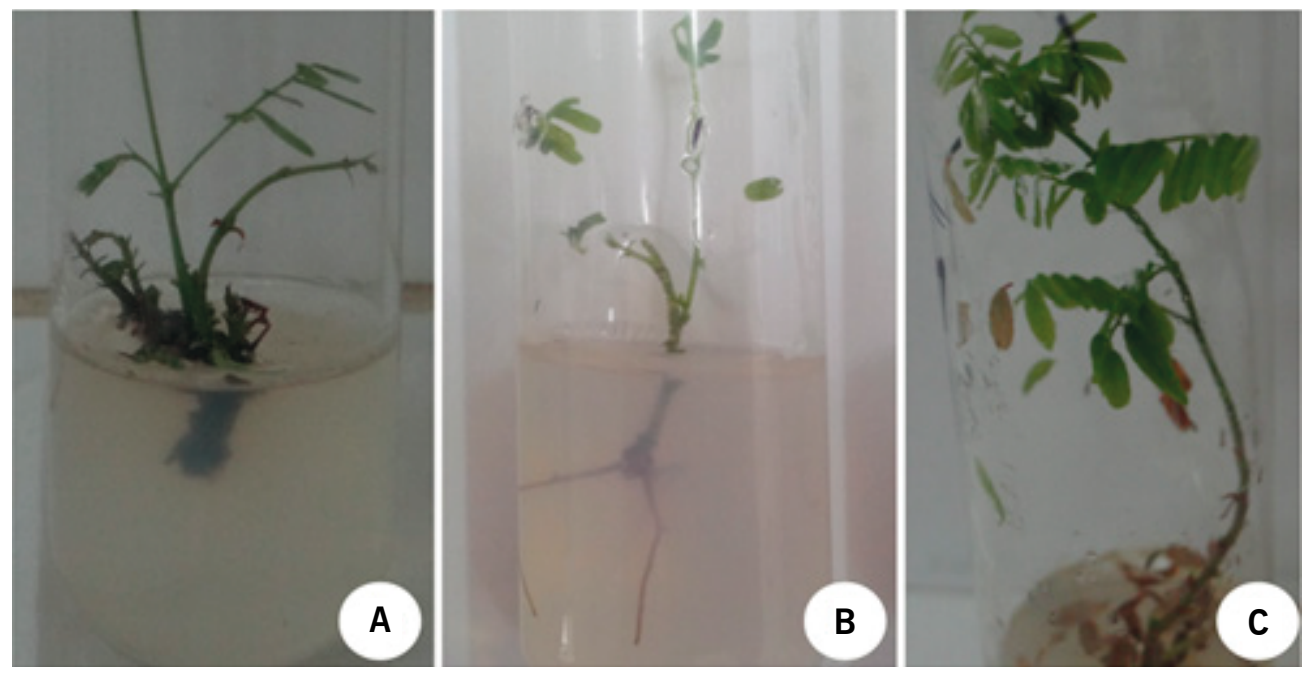

A. Multiplication of shoots in MS medium supplemented with $1.11 \mu \mathrm{M}$ of BAP, after three subcultures (90 days). B. Rooting of shoots in $1 / 2 \mathrm{MS}$ medium supplemented with $4 \mu \mathrm{M}$ of NAA after 45 days. C. Development of shoots in MS medium.

Source: Elaborated by the authors (2019).

\section{Conclusion}

To use $1.11 \mu \mathrm{M}$ of BAP combined with $0.27 \mu \mathrm{M}$ of NAA in multiplication medium and performing three subcultures provides higher rates of shoot production per explant (2.24) and with high survival rate. Rooting medium containing $4 \mu \mathrm{M}$ of NAA and half of the concentrations of MS salts provided a higher percentage of rooting of the shoots (68\%).

\section{Acknowledgments}

We thank the IF SUDESTE MG, for the support and funding of this project.

\section{Micropropagação de Dalbergia nigra, uma espécie florestal brasileira ameaçada de extinção}

\section{Resumo}

Apresentamos neste trabalho a micropropagação de Dalbergia nigra, utilizando segmentos nodais oriundos de sementes germinadas in vitro. 0 material vegetal foi cultivado em meio MS suplementado com 6-benziladeninapurina (BAP: 0, 1,11 e 2,22 $\mu \mathrm{M}$ ) e ácido naftalenoacético (ANA: $0.27 \mu \mathrm{M}$ ), 
combinado com diferentes quantidades de subcultivo para indução de multiplicação de brotos. Brotos multiplicados foram cultivados em meio MS e 1/2 MS (meia-força) para enraizamento, suplementado com ANA (0 e $4 \mu \mathrm{M}$ ). Os dados foram submetidos à análise não paramétrica pelo teste de Kruskal-Wallis. Os melhores resultados para multiplicação de brotos foram obtidos utilizando 1,11 ou 2,22 $\mu \mathrm{M}$ de BAP, combinado com $0.27 \mu \mathrm{M}$ de ANA (meio de multiplicação) e realizando três subcultivos, fornecendo altas taxas de produção de brotos por explante (média de 2,24) e alta taxa de sobrevivência. Melhores resultados para enraizamento foram obtidos utilizando meio 1/2 MS suplementado com $4 \mu \mathrm{M}$ de ANA, fornacendo uma alta porcentagem de enraizamento dos brotos (média de $68 \%$ ).

Palavras-chave: Jacarandá-da-Bahia. Propagação in vitro. Organogêneses.

\section{References}

BARTLETT, M. S. Properties of sufficiency and statistical tests. Proceedings of the Royal Society of London, v. 160, p. 268-282, 1937. Availableat: https://doi.org/10.1098/rspa.1937.0109. Access on: 09 sep. 2019.

BONGA, J. M.; VON ADERKAS, P. In vitro culture of trees. Kluwer, Dordrecht. 1992 . 236p.

DE MENDIBURU, F. Agricolae: statistical procedures for agricultural research. R package version 1.2-1. 2014. Available at: http://CRAN.R-project.org/package=agricolae. Access on: 09 sep. 2019.

FEARNSIDE, P. M. Desmatamento na Amazônia: dinâmica, impactos e controle. Acta Amazônica, v. 36, p. 395-400, 2006. Available at: http://dx.doi.org/10.1590/S0044-59672006000300018. Access on: 09 sep. 2019.

FERMINO JUNIOR, P. C. P.; NAGAO, E. O.; SCHERWINSKI-PEREIRA, J. E. Estabelecimento, germinação e multiplicação in vitro de teca (Tectona grandis L.f.) a partir de genótipos da Amazônia Sul-Ocidental. Scientia Forestalis, v. 37, p. 427-435, 2009. Available at: https://www.ipef.br/ publicacoes/scientia/nr84/cap10.pdf. Access on: 09 sep. 2019.

FERMINO JUNIOR, P. C. P.; SCHERWINSKI-PEREIRA, J. E. Germinação e propagação in vitro de cerejeira (Amburana acreana (Ducke) A.C. Smith - Fabaceae). Ciência Florestal, v. 22, p. 1-9, 2012. Available at: http://dx.doi.org/10.5902/198050985074. Access on: 09 sep. 2019.

GONÇALVES, E. O.; PAIVA, H. N.; NEVES, J. C. L.; KLIPPEL, V. H.; CALDEIRA, M. V. W. Crescimento de Dalbergia nigra (Vell.) Allemão ex Benth sob diferentes doses de cálcio, magnésio e enxofre. Revista Árvore, v. 38, p. 251-260, 2014. Available at: https://doi.org/10.1590/S0100-67622014000200005. Access on: 09 sep. 19.

GONZAGA, A. L. Madeira: Uso e Conservação. Brasilia, IPHAN, MONUMENTA, 2006. Available at: http://portal.iphan.gov.br/uploads/publicacao/CadTec6_MadeiraUsoEConservacao.pdf. Access on: 09 sep. 19.

HUBNER, I. H.; SILVA, L. V. DA; CAPATTI, I.; FUMAGALI, E.; SOUTO, E. R. DE; GONÇALVES, R. A. C.; OLIVEIRA, A. J. B. DE. Multiplicação in vitro de Aspidosperma ramiflorum Muell. Arg. (Apocynaceae). 
Acta Scientiarum Health Sciences, v. 29, p. 63-66, 2007. Available at: http://dx.doi.org/10.4025/ actascihealthsci.v29i1.108. Access on: 09 sep. 19.

LLOYD, G.; MCCOWN, B. Commercially feasible micropropagation of Mountain Laurel, Kalmia latifolia, by use of shoot tip culture. International Plant Propagators Society, v. 30, p. 421-427, 1981. Available at: https://www.cabdirect.org/cabdirect/abstract/19830315515. Access on: 09 sep. 19.

MARTIN, G.; GEETHA, S. P.; RAJA, S. S.; RAGHU, A. V.; BALACHANDRAN, I.; RAVINDRAN, P. N. An efficient micropropagation system for Celastrus paniculatus Willd: a vulnerable medicinal plant. Journal of Forest Research, v. 11, p. 461-465, 2006. Available at: https://doi.org/10.1007/s10310006-0237-4. Access on: 09 sep. 19.

MARTINS, S. V. Recuperação de áreas degradadas: ações em áreas de preservação permanente, voçorocas, taludes rodoviário e de mineração. Aprenda Fácil: Viçosa. 2. ed., 2010, 270p.

MINISTÉRIO DO MEIO AMBIENTE - MMA. Portaria n. 443, de 17 de dezembro de 2014. Diário Oficial da União, 18/12/2014, Seção 1, p. 110-121, 2014. Available at: https://dados.gov.br/dataset/ portaria_443. Access on: 25 jan. 2021.

MURASHIGE, T.; SKOOG, F. A revised medium for rapid growth and bio-assays with tobacco tissue cultures. Physiologia Plantarum, v. 15, p. 437-496, 1962. Availableat: https://doi.org/10.1111/j.1399-3054.1962. tb08052.x. Access on: 09 sep. 2019.

NIETSCHE, S.; GONÇALVES, V. D.; ABREU, S. C.; PEREIRA, M. C. T.; SANTOS, F. A.; ABREU, S. C. DE; MOTA, W. F. DA. Tamanho da semente e substratos na germinação e crescimento inicial de mudas de cagaiteira. Revista Ciências Agrotécnicas, v. 28, p. 1321-1325, 2004. Available at: http://dx.doi. org/10.1590/S1413-70542004000600014. Access on: 09 sep. 2019.

PHULWARIA, M.; RAM, K.; GAHLOT, P.; SHEKHAWAT, N. S. Micropropagation of Salvadora persica a tree of arid horticulture and forestry. New Forest, v. 42, p. 317-327, 2011. Available at: https://doi.org/ 10.1007/s11056-011-9254-z. Access on: 09 sep. 2019.

PHULWARIA, M.; RAM, K.; HARISH, G. A. K.; SHEKHAWAT, N. S. Micropropagation of mature Terminalia catappa (Indian Almond), a medicinally important forest tree. Journal of Forest Research, v. 17, p. 202-207, 2012. Available at: https://doi.org/10.1007/s10310-011-0295-0. Access on: 09 sep. 2019.

R Core Team. R: A language and environment for statistical computing. R Foundation for Statistical Computing, Austria. 2018. Available at: http://www.R-project.org/. Access on: 09 sep. 2019.

RIBAS, L. L. F.; ZANETTE, F.; KULCHETSCKI, L.; GUERRA, M. P. Micropropagação de Aspidosperma polyneuron (Peroba-rosa) a partir de segmentos nodais de mudas juvenis. Revista Árvore, v. 29, p. 517-524, 2005. Available at: http://dx.doi.org/10.1590/S0100-67622005000400003. Access on: 09 sep. 2019.

ROSSI, E.; SARTORETTO, L. M. Propagação in vitro da farinha-seca. Pesquisa Florestal Brasileira, v. 33, p. 45-52, 2013. Available at: https://doi.org/10.4336/2013.pfb.33.73.361. Access on: 09 sep. 2019. 
SANJAYA, M. B.; RATHORE, T. S.; RAI, V. R. Micropropagation of an endangered Indian sandalwood (Santalum album L.). Journal of Forest Research, v. 11, p. 203-209, 2006. Available at: https://doi.org/ 10.1007/s10310-006-0207-x. Access on: 09 sep. 2019.

SHAPIRO, S. S.; WILK, M. B. An analysis of variance test for normality. Biometrika, v. 52, p. 591-611, 1965. Available at: https://doi.org/10.2307/2333709. Access on: 09 sep. 2019.

TRIPATHI, M.; KUMARI, N. Micropropagation of a tropical fruit tree Spondias mangifera Willd. through direct organogenesis. Acta Physiology Plant, v. 32, p. 1011-1015, 2010. Available at: https://doi.org/10.1007/s11738-010-0484-z. Access on: 09 sep. 2019.

ZANELLA, L. B.; FRANCISCON, L.; GRUNENNVALDT, R. L.; TOMASI, J. C.; DEGENHARDTGOLDBACH, J. Micropropagation of Pinus tecunumanii. Ciência Florestal, v. 28, p. 651-660, 2018. Available at: http://dx.doi.org/10.5902/1980509832058. Access on: 09 sep. 2019.

Received: September 10, 2019.

Accepted: May 29, 2020. 